\title{
Carbon Source in Strawberry Plantlets at an Early Stage
}

\author{
Kazuo ICHIMURA*, Kenkou TsujI*, \\ Masayuki ODA* and Masaaki NAGAOKA*
}

Carbon sources of tissue-cultured plantlets are sugars, for example, sucrose added to the culture medium or $\mathrm{CO}_{2}$ assimilated by photosynthesis. Since the plantlets have been shown to have insufficient photosynthetic activity ${ }^{1,2)}$, the sugar added to the medium is thought to be the main carbon source. Kozai et $a l .^{3-5)}$ found that photosynthetic activity of tissue-cultured plantlets was increased under high photosynthetic photon fluxes $(\mathrm{PPF})$ and $\mathrm{CO}_{2}$-enriched conditions. They ${ }^{3-5)}$ further showed that growth of plantlets under these conditions was greater than that under conventional in vitro conditions. Shiba and Nagaoka ${ }^{6)}$ also reported that growth of carrot plantlets derived from somatic embryo was stimulated by ventilating $\mathrm{CO}_{2}$-enriched air under a high PPF. These results indicate that $\mathrm{CO}_{2}$ serves as a carbon source under suitable conditions for photosynthesis. There has been, however, no quantitative analysis on the effectiveness of sugar and $\mathrm{CO}_{2}$ as the carbon source which plantlets utilize.

In the present study, we determined the main carbon source of strawberry at an early stage by using radioisotope.

Two pieces of a cell tray with 8 cells $(4 \times 2 \text { cells, cell volume; } 4 \mathrm{ml})^{7)}$ whose bottom had been opened were placed in a polycarbonate culture vessel $(1000 \mathrm{ml})$. Eight out of 16 cells were filled with supporting material made of ceramic wool (Biofibermat; Nippon Steel Chem. Co., Tokyo), and $170 \mathrm{~m} l$ of $\mathrm{MS}^{8)}$ liquid medium containing $3 \%$ sucrose. Strawberry (Fragaria grandiflora Ehrh. cv. Toyonoka) plantlets with three leaves were cut from tissue-cultured multiple shoots proliferated from apical meristem, placed on each supporting materials, and cultured at $25^{\circ} \mathrm{C}, 12 \mathrm{~h}$ light/12 $\mathrm{h}$ dark. The light intensity was about $100 \mu \mathrm{Em}^{-2} \mathrm{~s}^{-1}$. This value is two-thirds of that reported by Kozai et $a l .^{3-5)}$ but several times higher than that of conventional culture method. After 1 week of culture, plantlets were used for experiments.

Fig. 1 shows the experimental apparatus used to examine radioactivity assimilated by photosynthesis. An air bag $(220 l)$ was filled with air containing ${ }^{14} \mathrm{CO}_{2}$ generated from $\mathrm{NaH}^{14} \mathrm{CO}_{3}(2 \mu \mathrm{Ci})$. $\mathrm{CO}_{2}$ concentration of air in the bag was about $340 \mathrm{ppm}$. The air in the assimilation chamber containing the culture vessels was substituted by ventilating with labeled air in the dark. The vent hole of the culture vessel was closed during the uptake of ${ }^{14} \mathrm{C}$ under natural ventilation, whereas it remained open for the uptake under forced ventilation. The plantlets were then allowed to assimilate ${ }^{14} \mathrm{CO}_{2}$ by ventilating with labeled air at a flow rate of $0.5 \mathrm{l} / \mathrm{min}$. for $2 \mathrm{~h}$. The light intensity was about $100 \mu \mathrm{Em}^{-2} \mathrm{~s}^{-1}$. To examine radioactivity of ${ }^{14} \mathrm{C}$ taken up from sucrose, $100 \mu l$ of ${ }^{14} \mathrm{C}$-sucrose $(10 \mu \mathrm{Ci})$ was added to the medium, and the plantlets were kept for $2 \mathrm{~h}$ ventilated with unlabeled air using the above apparatus. Under these experimental conditions, both specific radioactivities of $\mathrm{CO}_{2}$ and of sucrose were about $0.67 \mu \mathrm{Ci} / \mathrm{mmole}$. After incubation, plantlets were dried at $80^{\circ} \mathrm{C}$ and radioactivity in the sample was measured by a liquid scintillation counter as

* National Research Institute of Vegetables, Ornamental Plants and Tea, Ano, Mie 514-23, Japan 

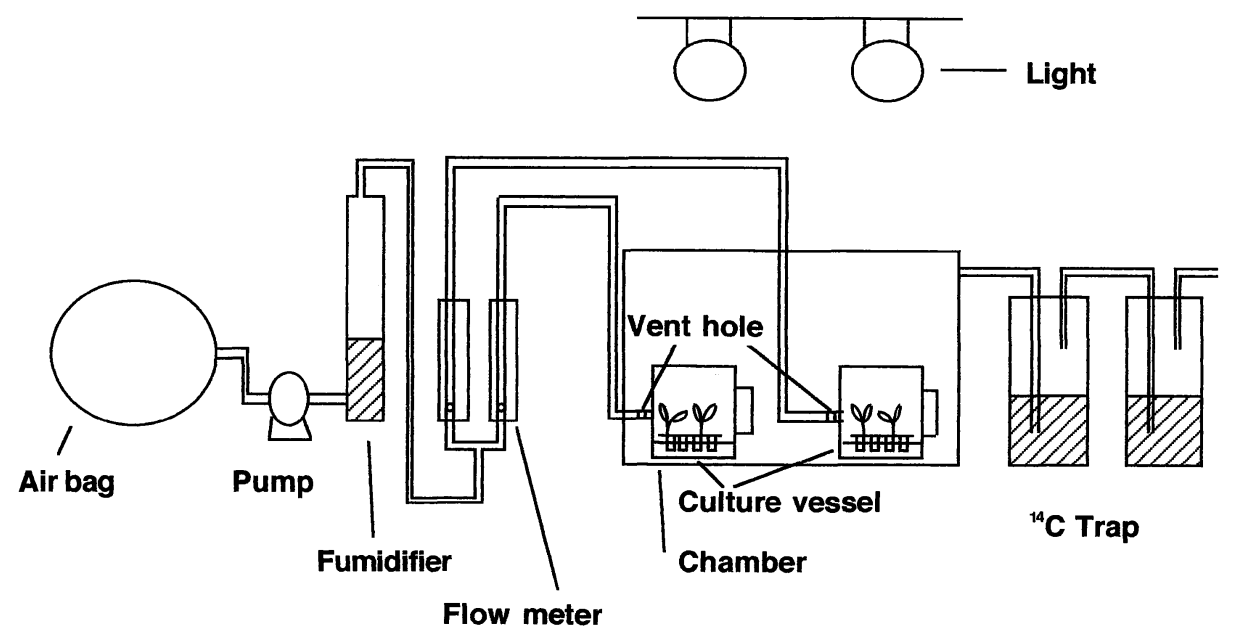

Fig. 1 Diagram showing the experimental apparatus.

Table 1. Uptake of ${ }^{14} \mathrm{CO}_{2}$ and ${ }^{14} \mathrm{C}$-sucrose of strawberry plantlets under forced or natural ventilation.

\begin{tabular}{crc}
\hline \multirow{2}{*}{ Ventilation } & \multicolumn{2}{c}{ Uptake } \\
\cline { 2 - 3 } & ${ }^{14} \mathrm{CO}_{2}$ & ${ }^{14} \mathrm{C}$-sucrose \\
& (dpm $\bullet$ carbon & number/dry weight $)$ \\
\hline Forced & $112 \pm 18$ & $1217 \pm 337$ \\
Natural & $29 \pm 5$ & $1223 \pm 232$ \\
\hline
\end{tabular}

Values represent the mean of 4 replicates and standard error.

described in Yoshioka et $a l^{9)}$. The results were expressed as the radioactivity per dry weight multiplied by the carbon number.

In the experimental system designed in the present study, specific radioactivity per molecule of $\mathrm{CO}_{2}$ was almost equal to that of sucrose. Further, for the experiment under natural ventilation, the air in the assimilation chamber was filled with labeled $\mathrm{CO}_{2}$. These conditions closely simulated actual culture conditions as above, and thereby the ratio of carbon source in tissue-cultured plantlets could be estimated.

Uptake of ${ }^{14} \mathrm{CO}_{2}$ under forced ventilation was 4 times greater than that under natural ventilation (Table 1), indicating that the plantlets at an early stage have photosynthetic activity. Uptake of ${ }^{14} \mathrm{C}$-sucrose under either forced or natural ventilation was 10 times greater than that of ${ }^{14} \mathrm{CO}_{2}$ under forced ventilation. On the other hand, there was no difference in radioactivity derived from sucrose between forced and natural ventilation(Table 1). These results indicate that the main carbon source of cultured strawberry plantlets at an early stage is sucrose. Photosynthetic activity of tissue-cultured plantlets at an early stage is known to be relatively insufficient ${ }^{1,2)}$. Kozai et $a l .^{3-5)}$ also reported that plantlet growth was not promoted under high $\mathrm{PPF}$ and $\mathrm{CO}_{2}$-enriched conditions at an early stage. The results obtained in this study support the finding that plantlets at an early stage primarily grow heterotrophically.

(Accepted June 25, 1994) 


\section{References}

1) Donnely, D. J., W. E. Vidaver, 1984. J. Amer. Soc. Hort. Sci., 109: 177-181.

2) Laetsch, W. M., D. A. Stetler, 1965. Amer. J. Bot., 52: 798-804.

3) Kozai, T., Y. Iwanami, K. Fujiwara, 1987. Plant Tissue Culture Letters, 4: 22-26 (in Japanese).

4) Kozai, T., Y. Iwanami, 1988. J. Jap. Soc. Hort. Sci., 57: 279-288.

5) Kozai, T., K. Sekimoto, 1988. Environ. Control in Biol., 26: 21-29 (in Japanese).

6) Shiba, H., M. Nagaoka, 1988. Abstr. Jap. Soc. Hort. Sci. Spring Meet., 242-243 (in Japanese).

7) Motooka, S., K. Konishi, M. Konishi, K. Sawa, M. Satake, K. Konishi, 1992. J. Jap. Soc. Hort. Sci., 60: 971 -979 (in Japanese).

8) Murashige, T., F. Skoog, 1962. Physiol. Plant., 15: 473-497.

9) Yoshioka, H., K. Takahashi, K. Arai, M. Nagaoka, 1977. Bull. Veg. Ornam. Crops Res. Stn. Japan., A3: 31 -41 (in Japanese). 